\title{
BCAS1 wt Allele
}

National Cancer Institute

\section{Source}

National Cancer Institute. BCAS1 wt Allele. NCI Thesaurus. Code C54372.

Human BCAS1 wild-type allele is located within 20q13.2-q13.3 and is approximately 127 $\mathrm{kb}$ in length. This allele, which encodes breast carcinoma amplified sequence 1 protein, plays a role in tumorigenesis and is associated with more aggressive tumor phenotypes when altered. 